\title{
Faces of Islam in Two Regimes (Orde Baru's Regime and Reformasi's era); a comparative fiction of Pengabdi Setan in the year of 1980 and in the year of 2017
}

\section{Wajah Islam di dua zaman (era Orde Baru dan era Reformasi); sebuah perbandingan fiksi Pengabdi Setan tahun 1980 dan tahun 2017}

\author{
Zulkifli Makmur \\ Sekolah Tinggi Agama Islam Darud Dakwah wal Irsyad Kota Makassar \\ zulkifli.makmur@mail.ugm.ac.id \\ Delukman A \\ Politeknik Informatika Nasional \\ delukman@polinas.ac.id \\ Syahruni Junaid \\ UIN Alauddin Makassar \\ Syahruni.junaid@uin-alauddin.ac
}

\begin{abstract}
intisari
Artikel ini mengulas posisi islam di dua film Pengabdi Setan, yaitu di tahun 1980 dan adaptasinya di tahun 2017. Film kedua ini merupakan film garapan Joko Anwar, menampilkan bentuk berbeda dari film sebelumnya, tentu saja tanpa mengurangi struktur Pengabdi Setan sebelumnya. Melalui pengkajian diakronik oleh strukuralisme Saussurian, simbolisme mengalami pergeseran di setiap periode zaman. Perbedaan yang terjadi tentunya mengikuti pemaknaan, dan perkembangan estetika, serta perubahan nilai yang ontologis. Dari pemantauan tersebut, ditemukan bahwa wajah Islam melalui penyimbolan dan ritus-ritus yang ada di film Pengabdi Setan tahun 2017 tidak begitu mendominasi dibandingkan fim sebelumnya yang cenderung menjadikan ritus sebagai goal dari pengusiran setan. Wajah Islam di Pengabdi Setan tahun 2017 lebih mengedepankan semangat islam yang substansial dibandingkan ritus semata-mata.
\end{abstract}

\begin{abstract}
This article discusses position of Islam in two movies of Satanic Slaves (Pengabdi Setan), i.e that in 1980 and its remake in 2017. The remake of Pengabdi Setan is directed by Joko Anwar, showing different form from the previous film, indeed without losing structure of Pengabdi Setan in 1980. Through diachronic approach of Saussurian structuralism, symbolism has changed in every single period of time. The differences indeed follow the meaning and development of aesthetics, as well as changes of ontological values. Based on that, it is found that the faces of Islam through the symbolism and rites in the movie Pengabdi Setan 2017 are not dominant than the previous one because Pengabdi Setan 1980 tended to prior rites of Islam as the goal of exorcising. The face of Islam in Pengabdi Setan in 2017 priors to essence of Islamic spirit rather than mere rites.
\end{abstract}




\section{Reference}

Makmur, Z., A, D., \& Nur, A. (2020, October 26). Perempuan dalam Tubuh Laki-Laki Makassar; Sebuah proyeksi Pertunjukan Musik Inovatif Maskur Al-Alief, "Pasang dalam Bunyi-Bunyian Mangkasara". https://doi.org/10.31219/osf.io/x36c8

Makmur, Z. (2020, October 26). Demi Kopi; Apresiasi Tari Pong Tiku Karya Ridwan Aco. https://doi.org/10.31219/osf.io/m29ky

Makmur, Z. (2020, October 22). Negeri Berlinang Mitos (sebuah Ulasan Novel "Negeri Lima Menara" Karya Ahmad Fuadi). https://doi.org/10.31219/osf.io/tqc4i

Makmur, Z. (2020), October 22). Penjurian Sastra di Masa Kebiasaan Baru. https://doi.org/10.31219/osf.io/5vymt

Makmur, Z. (2020, October 17). Film Snowden; antara Paranoia dan Tipuan-Tipuan Klasik Amerika. https://doi.org/10.31219/osf.io/9hgc7

Makmur, Z., \& Sainuddin, I. H., S. (2020, October 10). Karenang di atas Canon (sebuah Apresiasi). https://doi.org/10.31219/osf.io/k6r94

Makmur, Z. (2020, October 13). Paradoks Hubungan antara Manusia, Lingkungan, dan Sains dalam Enam Sekuel Film Final Destination (Sebuah Pendekatan Self-Deconstruction). https://doi.org/10.31219/osf.io/eacgs

Makmur, Z. (2020, September 10). Dekonstruksi puisi "The Divine Comedy" karya Dante Alighieri dalam Novel "Inferno" karya Dan Brown. https://doi.org/10.31219/osf.io/cwypx

HERIANTO, H., Jusmiana, A., Jusmawati, J., \& Makmur, Z. (2020, June 21). Comparing Learningat-home Activities of Students Living in Cities and Those Living in Villages during the Covid-19 Pandemic. https://doi.org/10.31219/osf.io/m4x9b

Alwi, Andi M. S., Muhammad Arsyam, Ibnu H. Sainuddin, S, and Zulkifli Makmur. 2020. "PELESTARIAN LINGKUNGAN SEBAGAI IMPLEMETASI DAKWAH BI AL-HAL DAN WUJUD KESADARAN MASYARAKAT." OSF Preprints. August 18. doi:10.31219/osf.io/vf6qm.

Makmur, Z. (2020, August 2). Membangun Kesadaran Apokaliptik melalui Sastra di Masa Pandemi. https://doi.org/10.31219/osf.io/utvyk

Makmur, Z., Sainuddin, I. H., S, Arsyam, M., \& HERIANTO, H. (2020, July 4). Paradoxical Relationship between Humans, the Environment, And Science in Final Destination (Movies). https://doi.org/10.31219/osf.io/ukr4q

Makmur, Z. (2020, October 30). Penulisan Populer. https://doi.org/10.31219/osf.io/bepc6 